\title{
FACTOR ANALYSIS OF THE SULPHIDE PHASE IN MAFIC-ULTRAMAFIC ROCKS IN FINLAND
}

\author{
T. A. Ḧ̈KLI \\ Research Laboratory of Exploration, the Outokumpu Co., Outokumpu, Finland
}

ABSTRACT

$\mathrm{R}$-mode factor analysis is applied to the analytical data of the sulphide phase from 7751 mafic-ultramafic rock samples from Finland. Four factors, i.e. S-Cu, Ni, $\mathrm{Zn}-\mathrm{Co}$ and $\mathrm{Cu}$ factors are established, to which $95 \%$ of the total variance observed in $\mathrm{Ni}, \mathrm{Co}, \mathrm{Cu}, \mathrm{Zn}, \mathrm{S}, \mathrm{Ni} / \mathrm{S}, \mathrm{Co} / \mathrm{S}, \mathrm{Cu} / \mathrm{S}, \mathrm{Zn} / \mathrm{S}$ and $\mathrm{Ni} / \mathrm{Co}$ can be attributed. The distributions of the factor scores on the surface of two basic intrusives are presented. The normalised distributions of positive $\mathrm{S}-\mathrm{Cu}$ and $\mathrm{Ni}$ factor scores in Finland are given and discussed with the emphasis on explorational applications.

\section{Introduction}

The essential concepts of factor analysis were developed at the beginning of this century by Spearman (1904) and a school of investigators involved in psychometric research. In the 1930's and 1940's the method was significantly improved by Thurstone $(1931,1947)$ as well as Holzinger and Harman (1941).

Factor analysis aims at resolution in terms of theoretical variables. These variables cannot always be measured directly. However, response variables related to them can be measured, from which the theoretical variables can be determined.

In geology there are numerous problems to which factor analysis can be applied. However, until recently only a few works had been published related to the subject. Lonka (1967) has applied factor analysis to the salinity indicator elements in the Finnish Precambrian phyllites. Harris (1966) has studied mineral wealth as a function of geology in Arizona, New Mexico and Texas. A mention can also be made of the paper by Drew and Griffiths (1965).

Since 1963 the Exploration Department of the Outokumpu Company has been actively engaged in studies concerning the mafic and ultramafic rocks in Finland, the aim being the development of new petrochemical methods which could be applied to the exploration for nickel ores. Part of the findings of this programme have been reported previously (Häkli, 1963, 1968), Häkli and Wright, (1967).

Among other things attention has been focused on the variation in composition of the sulphide phase in the mafic and ultramafic rocks as represented by the concentration of $\mathrm{S}, \mathrm{Ni}, \mathrm{Co}$, $\mathrm{Cu}$ and $\mathrm{Zn}$. The theoretical variables which cause the observed variation in composition of the sulphide phase were determined on the basis of these response variables.

The purpose of this paper is to describe the results of a factor analysis applied to the analy- 
tical data of the sulphide phase of mafic and ultramafic rocks in Finland with the emphasis on explorational applications.

\section{Methods}

The sample for this study were collected during the years 1964-1968. The sample localities were chosen on the basis of the geological maps published by the Geological Survey of Finland and on those produced by the geologic staff of the Exploration Department of the Outokumpu Co. A total of 7751 samples was accepted for the study ranging from quartzdiorite to dunite. Serpentinites were not included due to the fact that appreciable amounts of nickel incorporated in the sheet silicates go into solution during the dissolving procedure, thus introducing a significant error in the composition of the sulphide phase.

The powdered samples were treated in hot concentrated nitric acid for half an hour to dissolve the sulphides, after which the insoluble matter was removed from the solution by means of a centrifuge. The solution was diluted immediately and analysed for $\mathrm{Ni}, \mathrm{Co}, \mathrm{Cu}$ and $\mathrm{Zn}$ by atomic absorption spectroscopy. The sulphur was determined with a Philips vacuum X-ray spectrometer provided with a chromium tube and a penta erythriotol crystal. Factor analysis was carried out at the computer centre of the Outokumpu Co equipped with an IBM 360/40 computer.

\section{R-mode factor analysis}

Factor analysis may proceed according to two distinct procedures known as the $\mathrm{R}$ - and Qmodes. In the former, attention is focused on variables, and the results follow from the inspection of an $\mathrm{n} \times \mathrm{n}$ matrix of correlations between all the pairs of variables. In the Q-mode, the correlations are taken between individuals, across samples.
The cumputational steps involved in a complete $\mathrm{R}$-mode analysis are as follows:

1) $r$-matrix

2) initial factor matrix

3) rotated factor matrix

Observational data are composed of numerical measurements of $\mathrm{n}$ response variables in $\mathrm{N}$ cases. The data are arranged in tabular form with $\mathrm{N}$ rows and $\mathrm{n}$ columns.

The natural system of which the observations are a reflection is assumed to consist of $\mathrm{m}$ causal influences $C_{\mathrm{f}}(\mathrm{f}=1,2,3 \ldots \mathrm{m})$ which may be either randomly related to each other or exhibit correlations due to common causes acting at a more remote level.

Each variable $\mathrm{X}_{\mathrm{j}}$ is assumed to be linearly determined by the $m$ causes $C_{p}$. The relative importance of the cause $C_{f}$ on the variable $X_{j}$ is indicated by the coefficient $c_{j p}$. Thus,

$$
\mathrm{X}_{\mathrm{j}}=\mathrm{c}_{\mathrm{j}_{1}} \mathrm{C}_{1}+\mathrm{c}_{\mathrm{j} 2} \mathrm{C}_{2}+\ldots \ldots+\mathrm{c}_{\mathrm{jp}} \mathrm{C}_{\mathrm{f}}
$$

In addition to the common factors influencing all the variables, a complete factor model also includes unique and error factors. As the term suggests, the unique factor influences only one variable. In general, factor analysis aims at defining only the common factors. The presence of the error factor has an important bearing on the selection of the method of factor extraction, factor rotation and the interpretation of the results. The objective of study is thus threefold: 1) to determine the minimum number of causal influences needed to account for the observed variations; 2) to identify these causal influences and 3) to specify for each variable the relative importance of each case.

The interpretation of the results requires that the initial factor matrix be rotated. The rotation may be either orthogonal or oblique. It is performed so that most of the loadings are made low except those that are most important in defining the meaning of the factor, which are made high. For further details of factor analysis 
TABLE 1.

Correlation matrix. 7751 samples from mafic and ultramafic rocks.

\begin{tabular}{|c|c|c|c|c|c|c|c|c|c|c|}
\hline & $\log \mathrm{Cu}$ & $\log \mathrm{Zn}$ & $\log \mathrm{Ni}$ & $\log \mathrm{Co}$ & $\log \mathrm{S}$ & $\log \mathrm{Cu} / \mathrm{S}$ & $\log \mathrm{Zn} / \mathrm{S}$ & $\log \mathrm{Ni} / \mathrm{S}$ & $\log \mathrm{Co} / \mathrm{S}$ & $\log \mathrm{Ni} / \mathrm{Co}$ \\
\hline $\log \mathrm{Cu} \ldots \ldots$ & & -0.063 & 0.324 & 0.342 & 0.467 & 0.579 & -0.436 & -0.046 & -0.263 & 0.200 \\
\hline $\log \mathrm{Zn}_{\mathrm{n}} \ldots \ldots$ & -0.063 & & -0.079 & 0.270 & 0.094 & -0.150 & 0.529 & -0.148 & 0.099 & -0.326 \\
\hline $\log \mathrm{Ni} \ldots \ldots$ & 0.324 & -0.079 & & 0.751 & 0.351 & 0.004 & -0.348 & 0.693 & 0.177 & 0.857 \\
\hline $\log$ Co $\ldots$ & 0.342 & 0.270 & 0.751 & & 0.492 & -0.107 & -0.256 & 0.345 & 0.208 & 0.304 \\
\hline $\log \mathrm{S} \ldots$ & 0.467 & 0.094 & 0.352 & 0.492 & & -0.451 & -0.795 & -0.431 & -0.7 & 0.023 \\
\hline $\log \mathrm{Cu} / \mathrm{S}$ & 0.579 & -0.150 & 0.004 & -0.107 & -0.451 & & 0.293 & & & 0.089 \\
\hline $\log \mathrm{Zn} / \mathrm{S} \ldots$ & -0.436 & 0.529 & -0.349 & -0.256 & -0.795 & 0.293 & & 0.277 & 0.699 & -0.303 \\
\hline $\log \mathrm{Ni} / \mathrm{S} . .$. & -0.046 & -0.148 & 0.693 & 0.345 & -0.431 & 0.351 & 0.277 & & 0.747 & 0.731 \\
\hline $\log \mathrm{Co} / \mathrm{S} \ldots$ & -0.263 & 0.099 & 0.177 & 0.208 & -0.749 & 0.425 & 0.699 & 0.747 & & 0.093 \\
\hline $\log \mathrm{Ni} / \mathrm{Co} \ldots$ & 0.200 & -0.326 & 0.857 & 0.304 & 0.123 & 0.089 & -0.303 & 0.731 & 0.093 & \\
\hline
\end{tabular}

the interested reader is referred e.g. to the excellent paper by Imbrie (1963).

The R-mode factor analysis of the sulphide phase dealt with in this study was based on the following response variables: $\mathrm{Ni}, \mathrm{Co}, \mathrm{Cu}, \mathrm{Zn}$, $\mathrm{S}, \mathrm{Ni} / \mathrm{S}, \mathrm{Co} / \mathrm{S}, \mathrm{Cu} / \mathrm{S}, \mathrm{Zn} / \mathrm{S}$ and $\mathrm{Ni} / \mathrm{Co}$. Of these, the latter, i.e. the $\mathrm{Ni} / \mathrm{Co}$ ratio, reflects the silica content and the mafic index of the sample (Wilson, 1953; Fleisher, 1968) and thus also to some extent the crystallisation temperature. The metal to sulphur ratios were included on account of their simple relation to the corresponding metal content in the sulphide phase.

The frequency distributions of the above response variables are approximately lognormal. Consequently, instead of the variables themselves, their logarithms were subjected to a correlation analysis. Examination of the correlation matrix (Table 1) shows that cobalt correlates strongly with nickel whereas the other intermetal correlations, though positive and significant, are noticeably weaker. It is of interest to note the fairly high positive correlation between $\mathrm{Zn} / \mathrm{S}$ and $\mathrm{Co} / \mathrm{S}$ as well as between $\mathrm{Ni} / \mathrm{S}$ and $\mathrm{Ni}$ and $\mathrm{Co} / \mathrm{S}$. The Ni/Co ratio strongly correlates with $\mathrm{Ni}$ and $\mathrm{Ni} / \mathrm{S}$. This is due to the fact that the $\mathrm{Ni} / \mathrm{Co}$ increases towards the ultramafic end of the differentiation series (Wilson, 1953; Fleisher, 1968) as do also the total nickel and the percentage of nickel in the sulphide phase.
A factor analysis of the correlation matrix showed that four factors contained $95.1 \%$ of the information in the ten response variables (Table 2 ). Consequently, the dimensions of the space can be reduced 60 per cent without any significant loss of information.

Factor 1, which accounts for $33.4 \%$ of the total variance in the response variables, has a high positive loading on sulphur and a moderate positive loading on copper. It also has a fairly high negative loading for $\mathrm{Cu} / \mathrm{S}, \mathrm{Zn} / \mathrm{S}, \mathrm{Ni} / \mathrm{S}$ and $\mathrm{Co} / \mathrm{S}$. Thus, this factor may be attributed to the

TABLE 2.

Rotated factors and communalities

\begin{tabular}{|c|c|c|c|c|c|}
\hline & 1 & 2 & 3 & 4 & $\begin{array}{c}\text { Com- } \\
\text { munali- } \\
\text { ties }\end{array}$ \\
\hline $\log \mathrm{Cu} \ldots$ & 0.412 & 0.185 & 0.073 & 0.888 & 0.998 \\
\hline $\mathrm{Zn} \ldots$ & -0.126 & -0.139 & 0.925 & -0.076 & 0.897 \\
\hline $\mathrm{Ni} \quad \ldots$ & 0.137 & 0.982 & 0.066 & 0.088 & 0.996 \\
\hline Co ... & 0.220 & 0.710 & 0.559 & 0.108 & 0.877 \\
\hline$S \ldots$ & 0.944 & 0.206 & 0.256 & 0.023 & 0.999 \\
\hline $\mathrm{Cu} / \mathrm{S}$. & -0.454 & 0.002 & -0.162 & 0.875 & 0.999 \\
\hline $\mathrm{Zn} / \mathrm{S}$ & -0.881 & -0.260 & 0.345 & -0.065 & 0.968 \\
\hline $\mathrm{Ni} / \mathrm{S}$. & -0.595 & 0.788 & -0.134 & 0.068 & 0.998 \\
\hline $\mathrm{Co} / \mathrm{S}$. & -0.893 & 0.309 & 0.138 & 0.058 & 0.916 \\
\hline $\mathrm{Ni} / \mathrm{Co}$ & 0.026 & 0.864 & -0.343 & 0.042 & 0.866 \\
\hline $\begin{array}{l}\text { Eigen- } \\
\text { values ... } \\
\text { Cumula- } \\
\text { tive per- } \\
\text { centage of } \\
\text { total vari- } \\
\text { ance..... }\end{array}$ & 33.34 & 65.13 & 81.17 & 95.14 & \\
\hline
\end{tabular}


agent giving rise to the formation of the ironpredominant sulphide phase in mafic-ultramafic rocks. Had the samples been analysed for iron, the iron percentage would obviously have also obtained a high positive loading for this factor. The reason why iron was not included among the analysed elements was, that due to the small amounts of sulphides present, it would have been very difficult to avoid the dissolving of some non-sulphidic iron in the acid treatment, which would have thus caused a serious error in the composition of the actual sulphide phase. Moreover, the omitting of the sulphidic iron is well motivated because in basic and ultrabasic rocks the sulphide phase can be considered as a derivative of $\mathrm{FeS}$ a part of the iron of which is replaced by $\mathrm{Cu}, \mathrm{Ni}, \mathrm{Co}$ and $\mathrm{Zn}$ to produce chalcopyrite, pentlandite and sphalerite. Thus in this simplified model of the sulphide phase there are only five independent variables and the determination of the sixth, - in this case iron, would not materially increase the information.

Factor 2 exhibits strong positive loadings on $\mathrm{Ni}, \mathrm{Ni} / \mathrm{S}$ and $\mathrm{Ni} / \mathrm{Co}$ and a moderate loading on Co. It may be considered to reflect the cause responsible for the formation of nickel mineralisations.

The high positive loading for $\mathrm{Zn}$ and the moderate positive loading for $\mathrm{Co}$ on the third factor suggest that it might represent the affinity of $\mathrm{Zn}$ and Co for the acid differentiates of plutonic rocks, thus, among other things, enriching the sulphide phase of these rocks in $\mathrm{Zn}$ and $\mathrm{Co}$ in relation to $\mathrm{Ni}$ and $\mathrm{Cu}$.

The fourth factor has a strong positive loading on $\mathrm{Cu}$ and $\mathrm{Cu} / \mathrm{S}$, the rest of the loadings being insignificant. It reflects the agents which tend to segregate copper from the other metals to form mineralisations characterized by a copperpredominant sulphide phase.
The effect of these four causal influences is evident to anybody familiar with the types of sulphide mineralisations encountered in maficultramafic rocks. Chamberlain (1967) reports the fractionation of the sulphide phase in the Muskox intrusion into nickel-iron sulphide facies, copperiron sulphide facies and iron sulphide facies, which clearly correspond to the nickel, copper and sulphur factors of the present study. The segregation of copper from the other sulphide forming metals is characteristic of practically every sulphide nickel deposit described in the literature. In the Hardy mine (Mitchell and Mutch, 1956) any random mineralisation in the country rock of the nickel ore is usually high in copper. Segregation of copper has also taken place in the Frood mine (Hawley, 1965). The copper-rich sulphide phase in the Skaergaard massif (Wager, et al, 1957) is obviously also due to the effect of the copper factor. The lack of the nickel-rich sulphide phase in the Skaergaard intrusive may be only apparent since no information is available from the hidden lower part of the body. The sulphide mineralisations in the Ransko massif described by Pokorny (1969) also exhibit features which might be attributed to the factors obtained in the present study.

\section{Distribution of the factor scores in some basic intrusives}

The interpretation of the factors is considerably facilitated if factor scores are computed for the samples whose analytical data are submitted to factor analysis. This is usually accomplished in accordance with the formula given by Harris (1966).

$$
F_{i j}=\frac{a_{1 j}\left(x_{1 i}-x_{1}\right)}{S_{1}}+\frac{a_{2 j}\left(x_{2 i}-x_{2}\right)}{S_{2}}+\ldots+\frac{a_{n j}\left(x_{n i}-x_{n}\right)}{S_{n}}
$$


where $F_{i j}=$ the factor score of the $j$ th factor for the ith individual

$a_{p j}=$ the loading of the pth variable on the jth factor

$\mathrm{X}_{\mathrm{p}}=$ the mean of the pth variable

$\mathrm{S}_{\mathrm{p}}=$ the standard deviation of the pth variable

$\mathrm{i}=1,2, \ldots \ldots \ldots, \mathrm{n}$

$\mathrm{j}=1,2, \ldots \ldots \ldots, \mathrm{k}$

$\mathrm{p}=1,2, \ldots \ldots \ldots, \mathrm{m}$

$\mathrm{m}=\mathrm{k}$

$\mathrm{n}=$ number of individuals

$\mathrm{k}=$ number of factors

$\mathrm{m}=$ number of variables

It is a common practice to plot the factor scores on a map and to draw the appropriate contours. Two cases are described briefly to illustrate the application of the factors to the studies of basic intrusives. The samples taken from these intrusives were included in the pool of the samples and thus they contributed to the factoring. Consequently, the factor scores for these bodies are directly comparable with each other.

A few kilometres NE of the town of Forssa in SW Finland, there is a basic intrusive of a rather complex shape (Neuvonen, 1956). It is composed of rocks mainly ranging from quartzdiorite to pyroxene gabbro. In the southern part of the body, near the eastern contact, portions of hornblenditic rock have also been encountered. However, no olivine-bearing differentiates are known to expose. A total of 159 samples was collected from the intrusive.

Fig. 1 illustrates the distribution of the positive factor scores on the surface of the massif. The pattern suggests that the sporadic iron sulphide mineralisation is mainly controlled by two sets of subperpendicular zones running in WSWENE and NNW-SSE directions, respectively. This mineralisation is fairly low in intensity as is manifested by the modest values of the $\mathrm{S}-\mathrm{Cu}$ factor score which only exceed 2.0 twice.

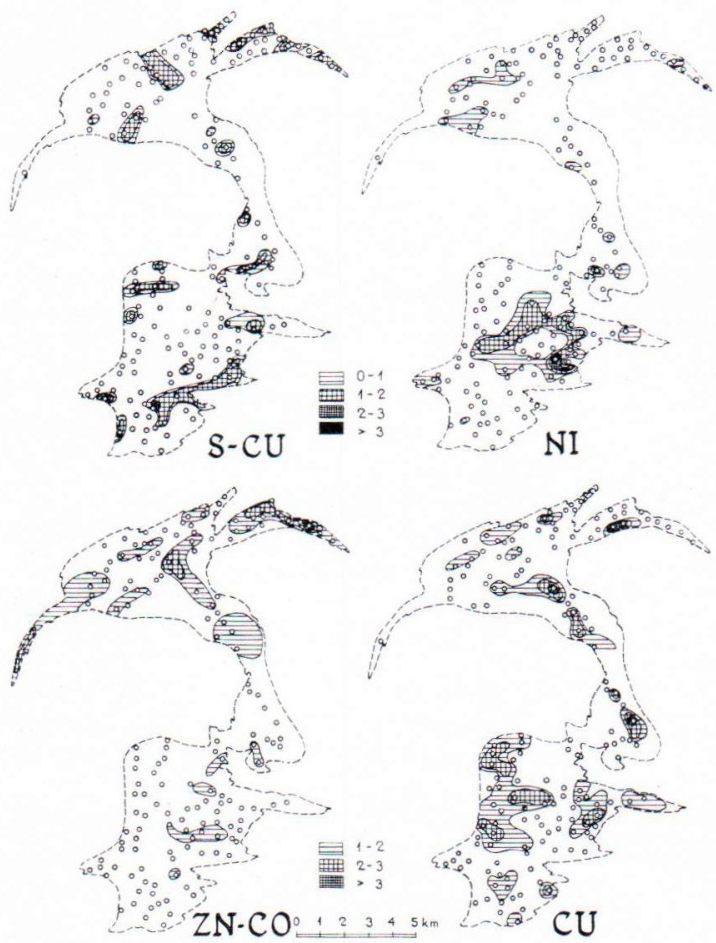

Fig. 1. Distribution of the factor scores on the surface of the Forssa gabbro massif. Circles indicate the sample localities.

An interesting ring pattern is caused by the nickel factor. Excluding the two hornblendite samples the rocks in the ring do not differ in mineral composition from those in the environment except that they are invariably richer in nickel. The information available is not sufficient to establish the cause of the ring structure. However, since the concentration of nickel increases towards the high temperature members of the differentiation series the pattern may reflect the form of the underlying feeding channel.

The positive $\mathrm{Zn}-$ Co factor scores are mainly restricted in the northern part of the intrusive and the pattern shows the same directional preferences as the S-Cu-factor.

The NNW-SSE control for the $\mathrm{Cu}-\mathrm{Cu} / \mathrm{S}$ factor is also clear, but in addition to it a discon- 
tinuous ring pattern appears in the same place as that caused by the Ni factor.

Examination of the distribution patterns for the four factors reveals that to some extent the nickel and copper factors seem to be related to each other in space and perhaps also in time. The other two factors were probably effective at a somewhat later stage in the development of the intrusive.

The second example deals with the Parikkala intrusive situated in SE Finland about 13 kilometres ENE of the village of Parikkala in the immediate vicinity of the border with the USSR. The intrusive has been described by Enkovaara (1945) and Papunen (1962). Häkli (1968) has studied the distribution of nickel in its silicates and discussed the model crystallisation temperatures.

A total of 136 samples collected from the intrusive were included in the factor analysis. Contrary to the Forssa massif the positive $\mathrm{S}-\mathrm{Cu}$ factor scores cover the major part of the surface of the Parikkala intrusive indicating that, compared with the other rocks sampled for the factor analysis, this massif is relatively rich in sulphur (Fig. 2). The distribution pattern of the high anomalies reflects the two subperpendicular fracture directions, i.e. those of SW-NE and WNW-ESE, respectively.

The highest nickel factor scores are confined to the southern part of the massif in the area where the ultramafic high temperature differentiates are mainly encountered. It is also noteworthy that the intensity of the anomaly over a fairly extensive area exceeds that encountered in the Forssa intrusive.

The distribution pattern of the positive $\mathrm{Zn}-$ Co factor scores is controlled by the two abovementioned sets of fracture zones. Comparison of the $\mathrm{S}-\mathrm{Cu}$ and $\mathrm{Zn}-\mathrm{Co}$ factor scores with each other, however, reveals that while some fracture zones control both factors, some others are manifested by only one of the factors.

Parallel to the Forssa case the copper factor in Parikkala also clearly correlates in space with
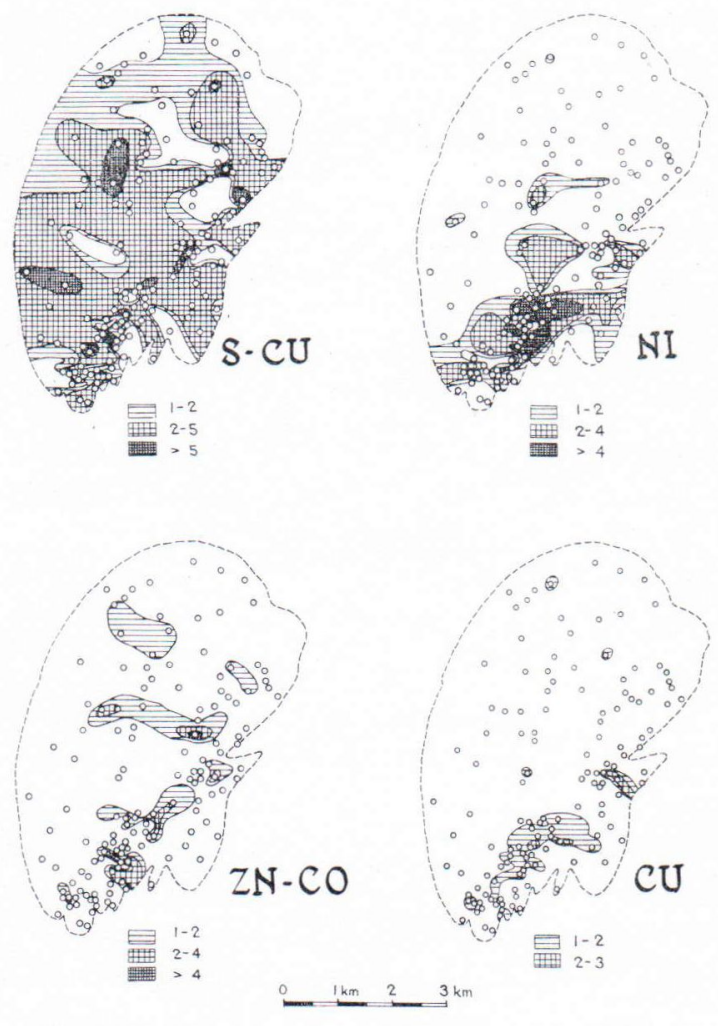

Fig. 2. Distribution of the factor scores on the present surface of the Parikkala gabbro massif.

the nickel factor. This is obviously due to the well-known fact that nickel ores often contain appreciable amounts of copper which, however, do not closely follow the nickel mineralisation but tend to become enriched in the environment ores. Thus the $\mathrm{Cu}-\mathrm{Cu} / \mathrm{S}$ factor seems to reflect this tendency also here.

If the Forssa and Parikkala cases are compared with each other in the light of nickel prospecting, the distribution and intensity of the factors presented above clearly favour the latter. In the Parikkala massif the nickel factor has been very effective, which, together with the presence of sulphur (high values of the $\mathrm{S}$-Cu-factor), places the intrusive in the rank of the potential host rocks for the nickel ores. 


\section{Regional distribution of the factor scores}

Although in principle nickel ores may be found in association with almost any basic or ultrabasic rock, it is obvious that the probability of the occurrence of an economic nickel mineralisation is not equal in every intrusive but fluctuates within a large range. The sampling for this study was planned so as to reveal a preference in the distribution, if any, of those intrusives in Finland which, due to their geochemical characteristics, appear the most promising for the occurrence of sulphidic nickel ores.

To study this distribution normalised distributions of the mafic-ultramafic bodies with factor scores exceeding 1.0 were computed. A rectangular grid of $20 \times 20 \mathrm{~km}$ was superimposed over a 1:1000 000 scale map of Finland and the $\mathrm{X}-\mathrm{Y}$ coordinates of the sample localities were converted into new $\mathrm{U}-\mathrm{V}$ cordinates of the grid. Each $20 \times 20 \mathrm{~km}$ square was further subdivided into $1 \mathrm{~km}^{2}$ squares. All the samples from one small square with a factor score exceeding 1.0 were considered to represent a single body. This procedure was considered necessary to reduce the effect of the uneven sampling frequency. The numbers of these "positive» $1 \mathrm{~km}^{2}$ squares, and thus the numbers of the "positive" bodies, within the $20 \times 20 \mathrm{~km}$ grids were computed and divided by the total number of the positive $1 \mathrm{~km}^{2}$ squares in the country. The relative frequencies thus obtained were subsequently contoured with the aid of a computer operated plotter using 2 per mil both as the lowest contour and the contour interval.

For the explorational goals the areal distribution of the S-CU and NI-Co factor scores are of greatest interest and they only will be presented here. The normalised distributions of the mafic-ultramafic bodies with $\mathrm{S}-\mathrm{Cu}$ and $\mathrm{Ni}-\mathrm{Co}$ factor scores exceeding 1.0 are illustrated in Figs. 3 and 4, respectively. On account of the general distribution of the basic rocks in Finland (e.g. Mikkola and Niini, 1968) the patterns in Figs. 3 and 4 have many features in common.

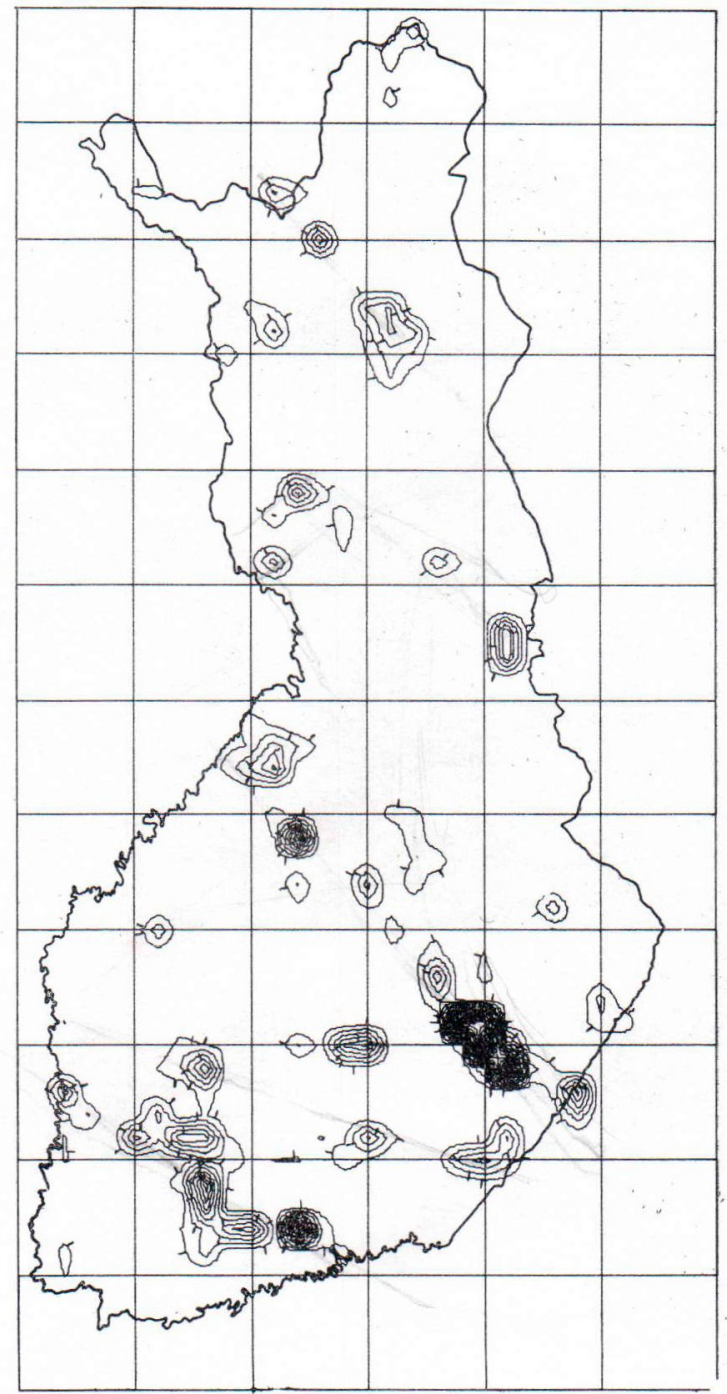

Fig. 3. Normalised distribution of the $\mathrm{S}-\mathrm{Cu}$ factor score in mafic-ultramafic rocks in Finland. The lowest contour and the contour-interval is 2 per mil.

Thus, it is seen that two zones run accross the country, one in a NW-SE direction from Nivala to Parikkala and the other in a W-E direction from Pori to Lappeenranta. The first zone which runs parallel to and in the continuation of the western shore of Lake Ladoga is a well-known zone of economic mineralisation including deposits such as Parikkala, Kotalahti, Makola and Hitura, not to mention several 


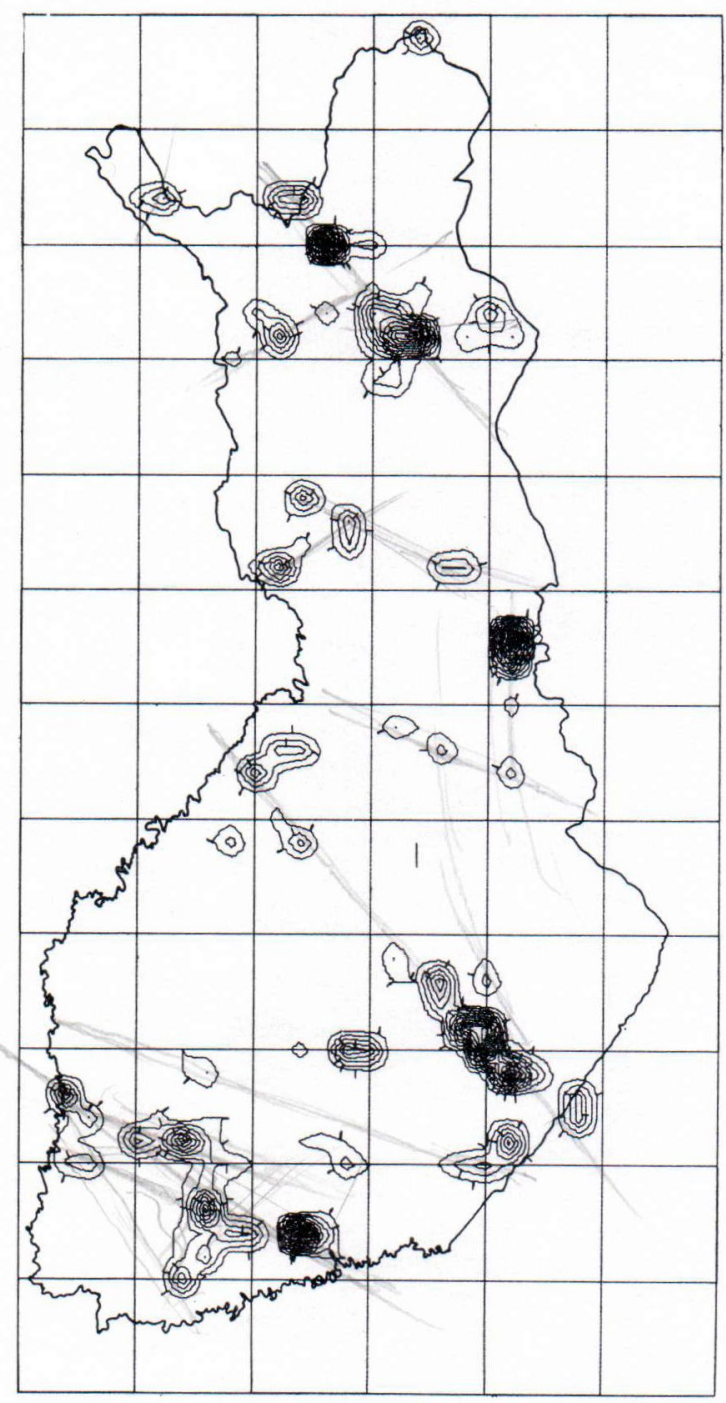

Fig. 4. Normalised distribution of the Ni factor score in mafic-ultramafic rocks in Finland. The lowest contour and the contour-interval is 2 per mil.

smaller ones. In essence it runs within the ore zone I of Mikkola and Niini (1968) being, however, narrower. The second zone, which includes the nickel mineralisations of Hyvelä, Harjunpää, Tyrvää, Kylmäkoski and Telkkälä (Viluksela, 1966), seems to intersect the first zone near the NW corner of Lake Ladoga. It is characteristic of those zones that in both of them iron sulphide and nickel sulphide mineralisations are encountered either within the same or in different intrusions.

In addition to these two zones positive factor scores are met with in the triangle NummiForssa-Mäntsälä in south Finland. Mafic rocks in Lapland and in the area of Kemi-RanuaTaivalkoski-Suomussalmi also show positive values.

Examination of Fig. 3 reveals that the basic rocks in Lapland are on the whole poorer in sulphur than the corresponding rocks in the rest of the country. On the other hand, the Lappish mafic-ultramafic rocks have fairly high values of $\mathrm{Ni}$-Co factor score, which, on account of the scarcity of sulphur, is partly due to the high content of nickel in the sulphide phase but perhaps also to the fact that some silicate nickel may have biased the analytical data of these rocks.

\section{Conclusions and summary}

Factor analysis of the sulphide phase of maficultramafic rocks indicates that about 95 per cent of the total variance observed in the numerical values of $\mathrm{Ni}, \mathrm{Co}, \mathrm{Cu}, \mathrm{Zn}, \mathrm{S}, \mathrm{Ni} / \mathrm{S}, \mathrm{Co} / \mathrm{S}, \mathrm{Cu} / \mathrm{S}$, $\mathrm{Zn} / \mathrm{S}$ and $\mathrm{Ni} / \mathrm{Co}$ can be attributed to four causal influences which, either alone or in combination cause most of the compositional variation observed in the sulphide mineralisations of the basic rocks. These factors are: $\mathrm{S}-\mathrm{Cu}$ factor, $\mathrm{Ni}$-factor, $\mathrm{Zn}-\mathrm{Co}$ factor and $\mathrm{Cu}$ factor.

The $\mathrm{S}-\mathrm{Cu}$ factor may be considered to represent the cause which gives rise to the formation of the iron-rich sulphide phase with a variable but often small content of copper.

With regard to explorational applications the nickel factor is the most important. It may be identified as the affinity of nickel for sulphur and early magmatic mafic silicates. Under favourable conditions, the factor produces economic nickel ores.

The existence of the particular copper factor and its close spatial relationship with the nickel 
factor reflects the agent which tends to expel copper from the other sulphide forming metals to produce copper-predominant mineralisations which often occur in the immediate vicinity of the nickel mineralisations.

The $\mathrm{Zn}-\mathrm{Co}$ factor has a causal connection with the affinity of $\mathrm{Zn}$ and Co for felsic rocks making them enrich in $\mathrm{Zn}$ and Co with a progressive differentiation in relation to $\mathrm{Ni}$ and $\mathrm{Cu}$. This factor is an interesting finding since the magmatic origin of the Nipyrrhotite ores has been questioned by some authors (e.g. Desborough, 1966) because no mechanism is known in which $\mathrm{Zn}$ can be separated from $\mathrm{Ni}$ and $\mathrm{Cu}$ in the early magmatic stages. However, the very existence of the $\mathrm{Zn}-\mathrm{Co}$ factor strongly suggests that such a mechanism really does work in basic and probably also in ultrabasic rocks.

The large number of samples and the method of sampling employed in this study warrant the general validity of the factors obtained. The application of the factors to studies of individual intrusives gives information which is of practical importance for the evaluation of the intrusive as a potential source of nickel ore. In this task the nickel factor is the most useful but the sulphur factor also offers some additional aid.

The regional distribution of the localities of those samples whose nickel factor scores exhibit high positive values reveals zones in which explorational activities should be concentrated and in which the probability of discovering new ore deposits is considerably higher than in the areas outside them.

Acknowledgements - The author is grateful to the Outokumpu Co. for permission to publish this paper. Dr. P. Haapala abd Mr. P. Isokangas read the manuscript critically and made suggestions relating to it. Mr. V. Suokonautio carried out the programming needed for the computer runs and the geological staff of the Exploration Department greatly contributed to the success of the field activities of this programme. To all these gentlemen the author wishes to express his cordial thanks.

\section{REFERENCES}

Chamberlain, J. A. (1967) Sulfides in the Muskox intrusion. Canadian Jour. of Earth Sciences. Vol. 4, pp. $106-153$.

Desborough George A. (1966) The significance of accessory magmatic sphalerite in basic rocks to the origin of nickeliferous pyrrhotite ores. Econ. Geol., vol. 61 , pp. $370-375$.

Drew L. J. and Griffiths J. C. (1965) Size, shape and arrangement of some oilfieilds in the U.S.A. Symposium on computers and computer applications in mining and exploration. vol. 3, University of Arizona, pp. FF $1-31$.

Enkovaara, A. (1945) Parikkalan Joensuun alueen geologiaa. Umpublished Thesis. University of Helsinki.

Fleisher, Michael (1968) Variation of the ratio Ni/Co in igneous rock series. Journ. of the Washington Academy of Sciences. 58, pp. 108-117.

Harris, De Verle P. (1966) Factor analysis a tool for quantitative studies in mineral exploration. Proceedings of the symposium and short course on computers and operations research in mineral industries. Mineral industries experiment station special paper. Vol. II, pp. GG1-37.
Hawley, J. E. (1965) Upside-down zoning at Frood, Sudbury, Ontario. Econ. Geol. Vol. 60. No 6, pp. $529-575$.

Holzinger, K. J. and Harman, D. H. (1941) Factor analysis, Univ. Chi. Press, pp. 1-417.

Häkli, Aulis (1963) Distribution of nickel between the silicate and sulphide phases in some basic intrusions in Finland. Bull. Com. Geologique de Finlande No 209. pp. $1-54$.

Häkl, T. A. and Wright, Thomas L. (1967) The fractional of nickel between olivine and augite as a geothermometer. Geochim. Cosmochim. Acta, Vol. 31 No 5, pp. $877-884$.

Ḧ̈кLI, T. A. (1968) An attempt to apply the Makaopuhi nickel fractionation data to the temperature determination of a basic intrusive. Geochim. Cosmochim. Acta, Vol. 32, No 4, pp. 449-460.

IMBRIE, JoHn (1963) Factor and vector analysis programs for analysing geologic data. Technical report No 6 of ONR Task No 389-135. Office of Naval Research. Northwestern University Evanston Illinois. pp. 1-83. Lonka, Anssi (1967) Trace-elements in the Finnish Precambrian phyllites as indicators of salinity at the time of Sedimentation. Bull. Comm. géol. Finlande 
Miknola, Armo K. and Ninn, Heik ki (1968) Structural position of ore-bearing areas in Finland. Bull. geol. Soc. of Finland. No 40. pp. 17-33.

Mrtchell, G. P. and Mutch, A. D. (1956) Geology of the Hardy mine, Sudbury district, Ontario. Canadian Mining and Metall. Bull. pp. 1-7.

Neuvonen, K. J. (1956) Suomen geologinen kartta. Lehti 2113, Forssa. Kallioperäkartan selitys. Explanation to the map of rocks. Geologinen tutkimuslaitos.

Papunen, H. (1962) Havaintoja Parikkalan Joensuunkylän gabromassiivista. Unpublished report. Outokumpu Co.

Pokorny, J. (1969) Sulphide ore deposits in the Ransko basic massif. Sbor. geol. ved, L.G. sv 10. pp. $111-115$.
Spearman, Charles (1904) General intelligence, objectively determined and measured. Amer. Jour. of Psychology, 15, pp. 201-293.

Thurstone, L. L. (1931) Multiple factor analysis. Psych. Rev., 38, pp. 406-427.

- (1947) Multiple factor analysis. Chicago. University of Chicago Press. pp. $1-535$.

Viluksela, Erkki (1966) Maamme malmivarat. Teknillinen Aikakauslehti 56. No 1, pp. 25-30.

Wa ger, L. R., Vincent, E. E. and Smales, A. A. (1957) Sulphides in the Skeargaard intrusion, East Greenland. Econ. Geol. Vol. 52, pp. 855-903.

Wilson, H. D. B. (1953) Geology and geochemistry of base metal deposits. Econ. Geol. Vol. 48, No 5, pp. $370-407$.

Manuscript received, December 4, 1969. 